\title{
Perceptions of Pre-Service Teachers' of Atatürk Teacher Training Academy regarding Classroom Management
}

\author{
Seçil Güneyhanli, Egemen Kemal Algan, Çağda Kivanç Çağanağa \\ European University of Lefke, Lefka, North Cyprus \\ Email: secilguneyhanli@gmail.com, egemenalgan2@gmail.com, ckivanc@eul.edu.tr
}

How to cite this paper: Güneyhanli, S., Algan, E.K. and Çağanağa, Ç.K. (2017) Perceptions of Pre-Service Teachers' of Atatürk Teacher Training Academy regarding Classroom Management. Open Access Library Journal, 4: e3918.

https://doi.org/10.4236/oalib.1103918

Received: August 30, 2017

Accepted: September 24, 2017

Published: September 27, 2017

Copyright ( 2017 by authors and Open Access Library Inc.

This work is licensed under the Creative Commons Attribution International License (CC BY 4.0).

http://creativecommons.org/licenses/by/4.0/

\section{(c) (i) Open Access}

\begin{abstract}
The aim of this study is to evaluate pre-service teachers' perceptions regarding classroom management, which consists of five dimensions. The study was also associated with the current literature. Consisting of qualitative research and scanning technique, this study aims to understand the five dimensions of classroom management by asking five open-ended questions, all of which were prepared with the help of experts' opinions. The data was gathered through face-to-face meetings by the participation of $4^{\text {th }}$ grade Primary School Teaching students $(\mathrm{n}=5)$ from Atatürk Teacher Training Academy. Content analysis was done to support the collected data. The findings were also compared with the department memos and the earlier findings regarding the five dimensions of classroom management. Consecutively, the problem sentence was found and it is widely acknowledged that contents of this study may help future studies on this subject.
\end{abstract}

\section{Subject Areas}

Education

\section{Keywords}

Northern Cyprus, Pre-Service Teachers, Classroom Management

\section{Introduction}

Learning is the process with which individuals develop certain characteristics based on their experience and occurs throughout individuals' whole lives. Education is basically planned and programmed learning, which happens in school-like settings. In planned learning, education is conducted by teachers [1]. 
Teachers, as being educational leaders, should teach the ways that go to information rather than giving information itself [1]. Pre-service teachers, who decided to become teachers, are the ones that attend Bachelor's Degrees at universities [2]. Teachers and pre-service teachers are stationed in schools for teaching purposes and thus this categorizes schools as places that were built to educate people. Educational management hierarchy matching the proper use of schools' funding means quality. Ensuring the quality of education in the classroom and the first and most fundamental layer of educational management is classroom management. Classrooms are being used by groups of students who are similar in age or educational satisfactoriness, and managing these classes is called classroom management [3]. The thing that impacts education the most is the five layers of classroom management and they consist of physical order, management of teaching, time-management, order of relationships and managing behavioral actions.

It has been widely accepted that there is a gap in the literature and for the purpose of closing this gap, there has been a question created. It goes as: "What is the perception of $4^{\text {th }}$ grade Primary School teaching students regarding classroom management?"

\section{Conceptual Basis}

The dimensions of classroom management will be evaluated in the following subtitles.

\subsection{Dimensions of Classroom Management}

Preparing the proper setting for teaching, removal of the things that might distract students, efficiently managing teaching time, making students actively engage in classroom activities, described as the classroom management has its dimensions that are studied similarly by variety of researchers [4].

\subsubsection{Physical Order of the Classroom}

Physical order can be described as the setting in which teaching activities occur. This setting impacts teacher-student relationships and students' attention and continuity [5]. Number of students, size, hygiene, color, lighting, appearance (esthetic) of the classroom and sitting arrangements are considered variables of the physical order.

a) Number of students: Number of students should be aligned with the grade of the students. There should be less number of students in the classroom of students in their first couple of years, who need their teachers' attentiveness and care more. The number of students per classroom number should be increased with the grade of the students [6]. Quoting Finn and Archilles, [5] expressed the fact that having less students in each classroom affects success of teacher-student.

b) Size of the classroom: The size of the classroom should be eligible in comparison of the number of students. There should be enough space left for both the teacher and students to act freely [7]. 
c) Lighting: There should be used a light neither a lot nor less than regular daylight. This lighting can be arranged by using big windows [8].

d) Color: It may have a positive impact on mental activity to have the colors in the classroom synched with each other. According to [9] compared to classrooms painted only with white, synched-color-painted classrooms tend to encourage positive behavior more.

e) Hygiene: The classroom should be cleaned daily for maintaining the best health conditions. In classrooms, which are beneath these health conditions, students tend to be sleepy and not attentive [5].

f) Appearance (Esthetic): It can be said that using matching and neatly organized furniture, having wide windows and classrooms and growing plants tend to positively impact students on their morale, perception and expectations [7].

g) Sitting arrangements: Learning and in-class interactions can be accomplished by adjusting the class' sitting arrangement in a way that lets everyone be in contact with the teacher and the subject teacher is teaching [10]. Sitting arrangements can be adjusted according to in-class activities, subject of the class and features, level and number of the students participating [9]. Sitting arrangements can be described as the way of the class' sitting order.

In line (column) order. Students sit in lines, facing the teacher and the board. This order is for more crowded classes. It is used in old-fashioned classical teaching.

Individual order. Desks for only one person is used. Main aim is individual learning and maintaining a space between students so that they do not affect each other [9].

Multiple-groups order. It is the order in which collaboration and team-work is forefront and is usually maintained by making several students sit with each other in one table. It is better used in classrooms which are not crowded [1].

One-group order ( $U$-shape, circle): Every student in class is considered in one group. It makes students actively engage in classroom activities and it makes rowdy behavior among students easy to detect [5].

There has not been much study about effects of physical order on classroom management but the studies that have been done suggest that it has crucial impacts. However, a study conducted by [11] implements on the fact that large classrooms with large number of students have higher success. This contradicts the statement of [1], which states that the success of the class is determined by how much time the teacher can spend on each individual student. Furthermore, the studies have stated that students that have problems with their sitting arrangements have higher academic success rates; which contradicts [1] opinion on comfortable settings' helping students' perception of learning.

Even though some studies contradict it, most of the studies underline the fact that the physical setting has an important impact on students.

\subsubsection{Time Management}

Time management is considered using class time efficiently in the classroom 
[12]. Time management can be examined with its two phases.

a) Time management before class time: Defining the class rules, making plans, preparing the sources and the tools to use in class are some works that are done to manage time during the actual class.

b) Time management in class time: Class should begin right on time and not finish early; teachers should never bring their personal problems to class; proper teaching techniques should be learned and used; important information about the subject should be given and the teaching process should never be interrupted [13].

According to a big number of studies conducted, time management is at utmost importance. In a qualitative study conducted on 18 teachers by [14] showed that teachers are aware of the importance of time management.

\subsubsection{Teaching Management}

Adjusting the classroom order, conducting the teaching, assessment and correction are the means of teaching management.

a) Planning of the teaching: It is the process of creating the content, teaching, evaluation and assessment methods in order to maintain expected behavior towards learning from students. What to teach during lesson and how and with which methods it is going to be taught is decided during planning period [9].

b) Conducting the teaching: It is the usage of the methods decided during planning in a proper order. Even though it may not always be in proper order, some of the methods are as follows; expressing motive, getting attention, stirring to action, content. According to [1] at this point teachers should encourage students to find the answer rather than presenting it to them.

c) Evaluation: in this process the students are evaluated regarding the behaviors their teachers expect them to have. This shows the success of the planning and conducting phases [10].

A study done on $434^{\text {th }}$ grade IELEV Private $125^{\text {th }}$ year elementary school students by [15] suggests that students are finding it effective to have active teaching methods. This study supports the need to have student-centered education.

\subsubsection{Relationships in Class}

When discussing relationships in class, one should highlight first days, class environment, democracy and class' fear and anxiety.

a) First days in class: Students tend to try their teachers on first days on what they would or would not do. This is why teachers should be decisive and show this to the students [9].

b) Democracy: In the name of democracy in the classroom, teacher should consider students' opinions, should decide with the students and let students decide on what to do and how to do it. Teachers, students and parents should all be involved in decision-making [8].

c) Fear, anxiety in class: Teachers should develop empathy so that they can banish fear and anxiety from class in order to maintain healthy learning experience. Empathy is the ability to put yourself in other people's shoes; think and 
feel like they do [10].

A study done by [14] on 18 teachers regarding efficient classroom management shows that in order to make students achieve self-confidence there should be warm interactions in class and that teacher should be exemplary to students.

\subsubsection{Behavioral Management}

Acts that can intervene with the subject being taught or abstract the teacher from teaching can be categorized as problematic behaviors [9]. Parents' participation in students' school life, supporting and guiding the students and positive encouragement are all ways of preventing and changing rowdy behavior [8]. Pre-decided class rules can help with the control of students' behaviors. There are some key points that should be taken when deciding on class rules. There should be low number of rules and they should be implemented fairly and just; the rules must include students' participation, rights and responsibilities [1].

Behavioral management is not just changing the immoral behavior but preventing from happening in the first place with well-designed class rules. Nick-naming others, not caring what is going on in the class and defying teachers are some examples of rowdy behavior [10].

[16] conducted a study on $4^{\text {th }}$ and $5^{\text {th }}$ grade Turkish students, 37 of which from Turkey, 36 of which from Norway; in order to understand the differences between Turkey and Norway on rewards and punishments in primary schools. Study showed that the students in Norway followed rules more compared to the students from Turkey. Regarding punishments, the students in Norway say that they receive verbal warnings while the students from Turkey say there are punishments. Furthermore, the students from Turkey say that there are a lot of rules and that their perception on discipline is negative. This study shows that positive re-encouragement and lesser number of class rules help with the controlling and preventing bad behavior in class.

\subsection{Northern Cyprus and Classroom Management}

In Northern Cyprus, there has not been much study in the field of classroom management. [1] evaluated teacher-student relationships in-class, in-school and outside school grounds on 176 teachers and 515 students. Study shows that through teachers' attention and friendliness towards students, they started to get more involved in in-class activities furthermore, students and teachers have developed efficient in-class and in-school relationships however, outside of school grounds they regard the relationship they have as insufficient. In another study with 589 students from public schools in Nicosia, Northern Cyprus was done to understand how the science teachers' relationships with students work. The study shows that there is a positive relationship between science teachers and their students [17].

\section{Methodology}

The research question of "What are the Perceptions of $4^{\text {th }}$ Grade Pre-service 
Teachers of Atatürk Teacher Training Academy towards Classroom Management regarding the five dimensions in Northern Cyprus?

- What are the perceptions of $4^{\text {th }}$ Grade Pre-service Teachers of Atatürk Teacher Training Academy towards physical order in Northern Cyprus?

- What are the perceptions of $4^{\text {th }}$ Grade Pre-service Teachers of Atatürk Teacher Training Academy towards time management in Northern Cyprus?

- What are the perceptions of $4^{\text {th }}$ Grade Pre-service Teachers of Atatürk Teacher Training Academy towards teaching management in Northern Cyprus?

- What are the perceptions of $4^{\text {th }}$ Grade Pre-service Teachers of Atatürk Teacher Training Academy towards relationships in class in Northern Cyprus?

- What are the perceptions of $4^{\text {th }}$ Grade Pre-service Teachers of Atatürk Teacher Training Academy towards behavioral management in Northern Cyprus?

These 5 sub-questions were created and practiced on teachers through faceto-face meetings. This study, which conducted with qualitative approach, is showed with a chart. Qualitative approach can be described as an approach that tries to understand every part of the world we live in. The chart tries to picture something is or was happening. This chart model does not change or contradict individuals or beings [18]. As this study being conducted with qualitative approach, the action taken is in a qualitative approach manner, which is asking questions to applicants face-to-face and gathering and analyzing findings. In face-to-face meetings one tries to understand the applicants by asking them questions about their thoughts on the subject. In analyzing one categorizes the findings gathered into similar groups and simplifies the findings into understandable context for readers or listeners [19]. The goal is to discover new meanings with the help of the summary of the study. There have been themes created during the analysis period by going through the questions of the study and understanding their relation. The codes and themes created have been matched with the studies on literature.

The perceptions of the $4^{\text {th }}$ grade pre-service teachers majoring primary school teaching in Northern Cyprus Atatürk Teacher Teaching Academy have been tried to be detected.

It is almost impossible to include all the teachers in Northern Cyprus to the study so we had to use coincidental and a randomly selection method with $4^{\text {th }}$ graders.

On ethical grounds, the participants' names are anonymous. They will be referred as ES-1, ES-2, ES-3, ES-4 and ES-5. ES-1, ES-2 and ES-3 are 21, ES-4 is 22 and ES-5 is 26 years old with 4 years of job experience.

In order to have valid results, not only accurate assumptions but also doable suggestions must be intact to use an acceptable data-gathering means [18]. In this study, suggestions from experts have been gathered and the pilot project was launched in order to have accurate and sound proofs for the research. Further- 
more, there are quotations from actual records as to being reliable.

\section{Findings and Comments}

\subsection{Perceptions of $4^{\text {th }}$ Grade Pre-Service Teachers of Atatürk Teacher Training Academy towards Physical Order in Northern Cyprus}

"What are the physical features you would recommend having in a classroom?" the first question of the study was asked to the participants.

Sitting arrangements. In U-sitting position as to achieve the widest eyesight and clarity according to technique, subject and number of students. Lighting. on a comfortable level, not too much not too less. Color. soothing, non-distracting.

ES-1, ES-2 and ES-5 state that it is crucial for all students to see the teacher. This statement supports the conclusion of [17] on the grounds that it is efficient to sit in $\mathrm{U}$ shape as it provides the most effective way of seeing and hearing. Here are some quotes;

"(ES-1): Students must be able to see the teacher at all times with the help of the sitting arrangement."

"(ES-2): For the teacher to see all of the students effectively."

"(ES-5): It is important that kids see each other."

ES-1 and ES- 5 have stated that sitting arrangements must be in order with the method of teaching. This statement agrees with the study of [9] which states that the sitting arrangement should be created according to the teacher's teaching technique. Here are some quotes;

"(ES-1): There must be a sitting arrangement according to what technique teacher is using in class."

"(ES-5): Sitting arrangement can change accordingly with the subject."

Only ES-5 has stated that there should be column order in crowded classes and round-shaped tables with groups, which proves the studies of [9] and [20]. [9] has also stated that the column order is efficient with crowded classes. Also according to [20], for small groups of students, round tables should be used so as to encourage team-work, sharing and helping others. Here are some quotes;

"(ES-5): Sitting arrangements should cooperate with the students. If group-work is needed, kids should be able to see each other clearly, thus they should sit in round-shaped tables. If the class is crowded, column shaped sitting arrangement should help with the control of the crowd."

ES-2 has stated that U-shaped sitting arrangement is proper for a sitting arrangement. ES-3 has also stated that U-shaped sitting arrangement should be used. This arrangement is what [5] recommended as a modern sitting arrangement.

"(ES-2): I think that sitting arrangement should be u-shaped in order for the teacher to see all of the students." 
"(ES-3): This setting should be used if the number of students is at a proper amount for the use of u-shaped sitting arrangement."

Regarding the lighting, there should be enough light as to stimulate daylight, not too much of it [8]. ES-2, ES-3 and ES-5 has agreed with this statement saying the light should be just right, and that too much light will distract students. This states that these example students understood the concept of lighting.

"(ES-2): The actual daylight that comes into class should be controlled so as to prevent a shining board."

"(ES-3): Lighting should be enough so that kids can see properly, not too much as it might give discomfort."

"(ES-5): The light should be just right because more light means uncomfortable and less light means sleepy kids."

Regarding the color, only ES-5 has stated that matching colors, which have positive effects on mentality of the students stated in the study of [9], should be used in class settings.

“(ES-5): Using matching colors for the class' walls and furniture can motivate students."

\subsection{Perceptions of $4^{\text {th }}$ Grade Pre-service Teachers of Atatürk Teacher Training Academy towards Time Management in Northern Cyprus}

Themes and codes have been created according to the question asked to participants.

Time management before class: planning the subject and the materials and class program. Time management during class: classes must always begin and end on time.

[9] stated according to time-management theme that making plans, setting rules and preparation before class makes it easier to manage time during hours. All of the participants have stated the efficiency of preparing before class. Here are some quotes;

“(ES-1): In order to manage time effectively, teachers should prepare for the class before coming."

“(ES-3): Efficient preparation and planning helps with time-management."

“(ES-4): The materials used in class should be prepared beforehand. Plans and preparations must be followed during class hours."

"(ES-5): If teachers prepare beforehand they would not have to think what they are going to do next and class will be working properly."

Only ES-5 has stated, agreeing with the study of [20] that classes must start on time and never end early or late.

"(ES-5): Time management is crucial for classes as well as the subject. Classes must never end earlier or later than expected. Teacher should never 
have to take break-time."

\subsection{Perceptions of $4^{\text {th }}$ Grade Pre- service Teachers of Atatürk Teacher Training Academy towards Teaching Management in Northern Cyprus}

We asked participants, "what are the teaching methods you recommend using in classes?", as $3^{\text {rd }}$ theme question and created new themes and codes according to their answers.

Planning of teaching. Every aspect should be prepared, subject must be studied. Executing of teaching. Learning through experience. Evaluation of teaching. teachers should evaluate both the students and themselves through asking questions, about both orally and written classes, questions and answers.

Whilst going through the educational management dimension, participants ES-1 and ES-5 stated the need to prepare for classes thoroughly. This agrees with the study of [9] which states that in the planning process the subject being taught, methods and techniques should be prepared beforehand. Here are some quotes;

"(ES-1): Materials of teaching should speak to all students and must be prepared before class."

"(ES-5): A teacher must prepare for all aspects of the subject. Teacher should review the subject, prepare examples, use presentations and prepare all of this with great consideration."

Whilst reviewing the execution of teaching theme, only ES-4 stated that it would be more permanent if live and learn technique is more involved. In the study of [20] it is clearly stated that in-class motivation and success can be increased by putting students' interest first and teaching student-centered technique.

“(ES-4): Using more live-learn tactics while teaching ensures more permanent results."

[10] have stated in their study that evaluating what students learned and how far they have come is important as well as evaluating the efficiency of planning and executing processes. Regarding the evaluation of teaching theme, all participants stated their own way of testing to understand whether their students managed to achieve the wanted behaviors and level of success. Here are some quotes;

"(ES-1): There should be questions-answers at the end of each class."

“(ES-2): Students' knowledge must be tested equally with questions-answers."

“(ES-3): Evaluation must be done by questioning students."

"(ES-4): Evaluation should be grading students by their answers during class, homework-making persistency and actively engaging with classroom activities."

"(ES-5): Evaluation of class can be done at the end of each class by asking 
questions written or verbally.”

The only different view on this subject came from ES-5;

"(ES-5): Finally, teacher should evaluate students and themselves considerately."

\subsection{Perceptions of $4^{\text {th }}$ Grade Pre-Service Teachers of Atatürk Teacher Training Academy towards Relationships in Class in Northern Cyprus}

"What is the basis of relationship points you would be willing to use in class?" question was asked to participants as the evaluation of the $4^{\text {th }}$ theme; new themes and codes were created accordingly.

Democracy: decisions must be made together and must be just. Fear and anxiety in class: empathy, not fear but respectfully understanding.

Regarding democracy in class theme, [8] has stated that teachers should care about students' opinions, give students chances to decide on in-class activities and anything else that is going on in class. When put through this question, ES-1, ES-3 and ES-5 have stated the importance of just and democratic decision-making in class. Here are some quotes;

"(ES-1): Teacher should make decisions with students and make their students feel like they are listened and cared for."

"(ES-3): Teachers should give their students the comfort of freedom of speech."

“(ES-5): Teachers should be just with their students. They should decide in-class activities with the help of opinions from their students."

When we look at the statements of ES-2 and ES-4 we see that their statements do not support [8]'s study. This shows the lack of understanding from ES-2 and ES-4. Here are some quotes;

"(ES-2): Students should respect their teacher. Teacher should decide the in-class activities beforehand."

"(ES-4): Teacher-student relationships must be in a respectful manner. Students should do what their teacher says."

Regarding fear and anxiety in class, [10] has stated the need to keep fear and anxiety away from class in order to maintain a proper class order. For doing this, a teacher should improve his/her ability to form engagements with students using empathy. Furthermore, [14] have stated that classes should have warm environments and that the teacher should always be a role model. It can be said that ES-1, ES-3 and ES-4 have acknowledged the fact that keeping fear and anxiety away from class improves class efficiency. Here are some quotes;

"(ES-1): Teachers should make empathy with students and make them feel like they are being listened."

“(ES-3): Teachers should have a relationship with their students not based 
on fear but mutual respect.”

"(ES-4): A teacher should be able to form empathy."

\subsection{Perceptions of $4^{\text {th }}$ Grade Pre-Service Teachers of Atatürk Teacher Training Academy towards Behavioral Management in Northern Cyprus}

The question "what are the regulations you think should be used in class?" was asked to participants. New themes and codes were created accordingly.

Class rules: The rules should be created with the help of opinions from students, should be small number of rules, and should be encouraging positive behaviors and thoughts. Correcting wrong behaviors: preventing the action, controlling it.

When discussing classroom rules, all participants agreed the need to establish rules with the students. This supports the statement of [20], which says "students should be involved with the process of establishing class rules." Here are some quotes;

"(ES-1): Class rules should be established with students."

“(ES-2): Rules need to be created with students."

“(ES-3): Rules agreed by students are more effective."

"(ES-4): Rules must be established with kids."

"(ES-5): Class rules must be established on the first day with cooperation of both the teacher and the students."

On the same subject, ES-1 stated that the need to have low number of rules, ES-2 stated the need to have the rules with positive attitude and ES-4 stated the need to have just rules. [20] states that the rules should compose of rights and responsibilities, must be just and established with the help of students, positive sentences and observable low number of rules. Here are some quotes;

"(ES-1): There should be small number of clear and understandable rules."

"(ES-2): Class rules should compose of curt and clear positive sentences."

"(ES-4): The class rules must be fair."

Regarding changing rowdy behavior in class, ES-2 and ES-5 have stated to need to detect troublemakers early and prevent inappropriate behaviors. According to [10], behavioral management is not only about creating class orders that can control bad behavior, but creating setting that can prevent it all together. We can say that ES-2 is supported by [10]. Here are some quotes;

"(ES-2): Teachers must detect troublemakers early and control them."

"(ES-5): Teachers should be able to prevent bad behavior without changing the mood of the class."

\section{Recommendations and Conclusion}

It is examined that participants from Atatürk Teacher Training Academy have an understanding about class order, lighting and color. It can be said that they 
have understood it in a way that can support studies that made on literature. ES-2, ES-3 and ES-5 have understood the lighting theme in a modern level. It can be said that another order theme, color, was only understood by ES-5. With this, it can be said that, participants other than ES-5 have partially understood. Regarding time management before class, participants have parallel perceptions with the studies except ES-2. Regarding time management during class, it can be said that only ES-5 has a qualified perception. Managing teaching involves planning, executing and evaluating of teaching. Regarding planning of teaching, only ES-1 and ES-5 stated views that can be found in literature. Regarding execution of teaching, it can be said that only ES-4 has a right opinion. We can regard all participants qualified regarding evaluation process. However, when we look at the answers from participants, we see that only ES-5 has commented parallel to modern concepts regarding qualitative evaluation process. Regarding $4^{\text {th }}$ dimension relationships, with the help of the quotes, democracy, anxiety and fear in class themes were created. It can be said that the first theme, democracy, was understood by all participants except ES-2 and ES-4. It is understood that another theme, anxiety and fear in class, was understood by ES-1, ES-3 and ES-4 as a "must be bound" way. When looked at the quotes from answers given regarding the $5^{\text {th }}$ dimension, behavioral management, we can see that all participants have an understanding in the modern manner about establishing class rules. It can be said that with the unwanted behaviors theme, only ES-2 and ES-5 have an agreement with literature.

Whilst looking quotes from interviews and studies in literature, we can say that ES-5 has a positive and prominent level understanding about classroom management. The reason for this is ES-5's job experience.

In order to answer main question of the study, with a totalitarian point of view, it can be said that all participants from Atatürk Teacher Training Academy have a partial understanding about the five dimensions of classroom management.

According to these conclusions, there are some suggestions below.

A cohort scanning model can be used throughout teaching students' school life until their start of job in order to make them have more trustworthy and reliable perceptions towards classroom management. Furthermore, parallel to the findings and studies in literature, all teachers should embrace and use the five dimensions of classroom management in order to maintain more eligible teach-learn environments in classrooms. In this content, teaching faculties should involve classroom management classes in their curriculum. There can be services helping not only teaching students but also real-time teachers to have more efficiency in classroom management. This study's population is limited to five dimensions. Studies done with bigger number of participants would be more valid, trustworthy and could be generalized in Northern Cyprus's population. Furthermore, with the use of observation and scale, future studies can have more eligible data. 


\section{References}

[1] Erden, A., Aytaç, T. and Altunçekiç, A. (2014) Higher Education Teacher-Student Relations: Northern Cyprus Example. Kastamonu Education Magazine, 22, 761-782.

[2] Aktepe, V. and Yalçınkaya, E. (2014) Practice of Teaching and School Experience (1. Print). Pegem, Ankara.

[3] Gökyer, N. and Özer, F. (2014) Perceptions of Pre-Teachers on Managing Classroom Efficiently. International Periodical for the Languages Literature and History of Turkish or Turkic, 9, 691-712.

[4] Babaoğlan, E. and Korkut, K. (2010) Classroom Management Abilities with Teacher's Self-Esteem. Inonu University Education Faculty Magazine, 11, 1-19.

[5] Başar, H. (2014) Classroom Management. 19. Print, Ani, Ankara.

[6] Karaçalı, A. (2006) Evaluation of Physical Variables That Can Affect Classroom Management. Gazi University Kirşehir Education Faculty, 7, 145-155.

[7] Aydın, A. (2015) Classroom Management. 18. Print, Pegem, Ankara.

[8] Balay, R. (2014) Classroom Management in 2000s. 5. Print, Pegem, Ankara.

[9] Kiran, H. (Ed.) (2012) Effective Classroom Management. 8. Print, Ani, Ankara.

[10] Şişman, M. and Turan, S. (Ed.) (2011) Classroom Management. 2. Print, Pegem, Ankara.

[11] Şensoy, S.A. and Sağsöz, A. (2015) Student Success with Physical Order of Classes. Ahi Evran University Kırşehir Education Faculty Magazine, 16, 87-104.

[12] Çubukçu, Z. and Girmen, P. (2008) Teachers' Opinions on Classroom Management Abilities. Bilig, 2, 123-142.

[13] Fisher, D. (2009) The Use of Instructional Time in the Typical High School Classroom. The Educational Forum, 73, 168-176. https://doi.org/10.1080/00131720902739650

[14] Doğan, S., Uğurlu, C.T. and Karakuş, H. (2014) Evaluation of Teacher Opinions on Effective Classroom Management. Gaziantep University Social Studies Faculty Magazine, 13, 1097-1119. https://doi.org/10.21547/jss.257178

[15] Ayva, Ö. (2010) Students' Opinions on Social Studies. ICONTE, 1, 276-281.

[16] Boyacı, A. (2009) İlköğretim öğrencilerinin disipline sınıf kurallarına ve cezalara ilişkin görüşlerinin karşılaştırmalı olarak incelenmesi (Türkiye-Norveç örneği). [A Comparative Study of Primary School Students' Opinions on Discipline, Class Rules and Punishment (Turkey-Norway Example).] Kuram ve Uygulamada Eğitim Yönetimi, 15, 523-553.

https://www.researchgate.net/publication/309722054_Sosyal_bilgiler_ogretiminde_s inif_yonetimi

[17] Kiraz, A. and Omağ, K. (2013) Perceptions of Students Regarding the Techniques of Classroom Management Science Teachers Use. Hacettepe University Education Faculty Magazine, 44, 198-211.

[18] Kincal, R.Y. (2015) Scientific Research Methods. 4th Print, Nobel, Ankara.

[19] Karataş, Z. (2015) Qualitative Research Methods on Social Studies. Permanent Social Services Magazine, 1, 62-80.

[20] Erden, M. (2014) Classroom Management. 2nd Print, Friend, Ankara. 
Submit or recommend next manuscript to OALib Journal and we will provide best service for you:

- Publication frequency: Monthly

- 9 subject areas of science, technology and medicine

- Fair and rigorous peer-review system

- Fast publication process

- Article promotion in various social networking sites (LinkedIn, Facebook, Twitter, etc.)

- Maximum dissemination of your research work

Submit Your Paper Online: Click Here to Submit

Or Contact service@oalib.com 